\title{
Innovative transport and logistics schemes in the Arctic zone of Russia as development drivers of the world economy
}

\author{
Natalya V. Baydukova \\ Department of Economics \\ St. Petersburg State University of Civil \\ Aviation \\ St. Petersburg, Russia \\ nv@baydukova.ru \\ Sergey A. Uvarov \\ Department of trade and merchandising \\ St. Petersburg State University of \\ Economics \\ St. Petersburg, Russia \\ s_uvarov@mail.ru
}

\author{
Mikhail N. Grigoriev \\ Department of Economics, organization \\ and production management \\ Baltic State Technical University \\ «VOENMEH» named after D.F. Ustinov \\ St. Petersburg, Russia \\ grigorievmn@ya.ru
}

\author{
Yuri Y. Mihalchevskiy \\ Rector's office \\ St. Petersburg State University of Civil \\ Aviation \\ St. Petersburg, Russia \\ mihalchevski_uu@spbguga.ru
}

\begin{abstract}
Planet climate changes, affecting the Arctic Ocean, open up new prospects for optimizing transport flows between Asian and European countries. Mankind has long sought to use these routes, but shipbuilding technologies did not allow doing this before. The combination of these factors allows Russia not only to provide short-sea cargo traffic, but also to provide transit facilities for such large exporters of goods as China, South Korea, Japan and to organize deliveries to these countries of raw energy and materials from the polar zone of Russia. The article discusses a number of original cost-effective schemes for the supply of energy from the polar zone of Russia to Europe and Asia.
\end{abstract}

Keywords-logistics, supply chain management, innovative technologies, the Arctic zone of Russia, the Northern sea route (логистика, управление цепями поставок, инновационные технологии, Арктическая зона России, Северный морской nymb)

\section{IMPACT OF CLIMATE CHANGE ON ARCTIC ECONOMIC DEVELOPMENT}

Climate warming in the Arctic creates prerequisites for a significant change in the direction and intensity of transport and trade flows within the world economy. The use of the Arctic ocean for the delivery of goods between Asia and Europe reduces the time of their transportation and, therefore, can attract a significant number of transport vessels.

Today, the average duration of ships movements from Asia to Europe on the route through the Suez takes approximately 34 days, and on the Northern Sea Route (NSR) - 23 days [1]. Another advantage of the NSR is the lack of queues in which ships stand when passing the Suez. The volume of traffic on the NSR in 2015 amounted to 4 million tons, in 2017 - 10 million tons and after 2020 the flow of cargo will increase to 40 million tons, by $2025-2030$ - to 80 million tons. Nowadays cargo turnover along the NSR has already surpassed the number of exports in the late $80-\mathrm{s}$, which was approximately 6 million tons. However, only $2 \%$ of the carriage is a product of transit for foreign countries.

The possibilities of the coming revolutionary changes in economic processes have caused a keen interest to the Arctic region from a number of states, whose territories lie relatively far away from it. First of all, it concerns India, China, the Republic of Korea, Singapore and Japan, which today partake as the permanent observes within the Arctic Council.

China is currently insistently seeking for promising directions of economic development, which will be in focus for many decades in future. Much attention is paid for the Arctic [2]. The authors consider it symptomatic that in 2013 the Polar Research Institute of China, PRIC, located in Shanghai, was connected with specialized scientific organizations of Northern Europe, as a result of which the China Nordic Arctic Research Centre appeared. Moreover, China considers the Arctic zone as the "Maritime Silk Road", which will allow to import materials from the West, and to supply Chinese goods to Europe by the shortest route, bypassing the high-risk shipping zones in the southern seas. No less interest among the Chinese cause minerals and bioresources of the Arctic.

The project "YAMAL LNG" is the first major energy cooperation project to be implemented in Russia after China's "One road, One belt" initiative. According to the agreement, after the 2nd and 3rd production lines of the "YAMAL LNG" project are put into operation, starting from 2019, the Chinese Corporation CNPC will import 3 million tons of "YAMAL LNG" project production annually. This project will stimulate the development of the Russian energy industry and at the same time accelerate the optimization of the energy structure in China.

Ports Dalian, Qingdao and two ports - Chongqing and Ryan, which are leased by China from the DPRK and whose situation has become complicated in connection with the 
negotiations between the U.S. and North Korea on the denuclearization of the latter, are fundamental for the China's Arctic exploration process.

To strengthen its influence in the Arctic, China is developing economic relations with smaller countries, which take part in the Arctic Council. Special attention from China is paid for country like Norway, especially in the context of its experience in deep-sea drilling, as well as participation in the development of the shelf, which went to Norway after the known agreements with Russia.

Close partnership in the Arctic was formed between China and Denmark, while the latter is expected to receive economic benefits from the climate warming in the North, which is already leading to a reduction in the ice cover of Greenland. The potential to participate in the extraction of rare earth elements in Greenland also received special attention from China.

There is also a significant influence of China in Iceland in the midst of the 2008 financial crisis China managed is successfully provide Iceland with a currency swap of 0.406 billion euros for emergency stabilization of its banking system. The development of the emerging trend was the 2012 Agreement with Iceland on cooperation in the Arctic and the 2014 Agreement on the free trade zone, as well as the statement of China National Offshore Oil Corporation on joint work on the exploration of oil reserves off the South-Eastern coast of Iceland with Eykon Energy [2].

Thus, in the North Atlantic, China has formed a zone of economic and political interests, which in the near future has a strategic character for the country. The shortest way from this zone to the coast of China lies through the Arctic, so its development is an urgent task for China, at least for the next century.

Japan, while assessing what has happened, announced in mid-2009 its desire to obtain permanent observer status of the Arctic Council. As a logistics base for their activity in the Arctic, the Japanese consider the port city of Tomakomai (Tomakomai) at the orifice of the river of the same name, located to the Southeast of the city of Sapporo. Today, its turnover exceeds 45 million tons per year. Raid depth reach 25 $\mathrm{m}$, which allows to handle large vessels. Today, it exports engineering products and receives coal, oil, petroleum products, roundwood and finished timber from abroad.

The government of the Republic of Korea established in 1987 Polar Research Center, PRC. From this moment on, the National Program for the Development of the Polar Regions is being implemented there. The first Korean research icebreaker Araon was built in 2009. In 2013, a ship built in the Republic of Korea under the national flag of its country made the first transition through the Russian Arctic from the Russian port of Ust-Luga to the Korean port of Gwangyang. Then another ship from the Republic of Korea delivered equipment through the Arctic to the Yamal Peninsula for Russian gas producers. Such activity of Korean vessels in the Russian Arctic is based on the fact that such national shipbuilding companies as Daewoo Shipbuilding and Marine Engineering (DSME), Hyundai Heavy Industries (HHI), Samsung Heavy Industries (SHI) are the most effective in the world in creating specialized ice class vessels. The Institute of Arctic Logistics exists at the Yongsan University in South Korea, which holds the annual international conference "Transport and Logistics in the Arctic." A distinctive feature of the economy of the Republic of Korea is the presence of large commercial and industrial groups that have strong state support. To this circumstance, Korea's successes in high-tech sectors of the economy are due to a large extent. South Korea can conduct intensive development of the Arctic, relying on the largest national ports of Busan, Ulsan, Gwangyang. TPI Megaline shipping company from the Republic of Korea has extensive experience in transporting oversized cargo to the Russian Yamal Peninsula in the Arctic port of Sabetta. Of significant interest for trans-Asian cooperation is the project for the transport of water through the Arctic and further along the $\mathrm{Ob}$ River to Pavlodar of heavy goods from Korea and Japan to Kazakhstan, proposed by Unico logistics.

Not being actually the states of the Arctic region, China, the Republic of Korea and Japan have the financial, technological and infrastructural capabilities for intensive development of the Arctic. These capabilities surpass the potential of Russia in most parameters. In the media of these states, and often at the state-media level, the idea is being made that the Arctic zone is the property of the entire world community and its economic use should be unlimited by the efforts of all countries that have the corresponding desire. These states strive to change the legal status of the Arctic in order to transfer the sea routes established there under international management.

\section{PROPOSED LOGISTICS SCHEMES}

In view of the above, our country faces a strategic problem of protecting the Russian Arctic region as a promising resource base and an important transport artery of global importance, in a way feasible for our economy, relying on the capabilities of modern logistics [5,6].

According to the authors, it is advisable to solve this problem with the help of innovative logistics technologies, setting a goal to increase the economic efficiency of solving promising problems. To find the necessary solutions, the methodology based on the supply chain management paradigm (SCM) should be used, which provides the achievement of the intended result not so much the intensification of the use of existing competitive advantages as the production of new competitive advantages. Next, we consider a number of innovative logistics schemes that can be drivers of global economic development [7, 8].

Russia, despite the existing economic problems, retained as a Soviet legacy about 40 icebreakers, including four nuclear. In St. Petersburg on the Baltic shipyard was launched from the slipway atomic icebreaker "Arktika", the lead ship of the new project 22220 , on the same plant are in operation two serial ship "Ural" and "Siberia" of the same project. Today they are the largest and most powerful in the world, being able to overcome 3-meter ice. There are plans to build even more powerful icebreakers, the construction of which is planned at the Zvezda shipyard in Primorsky Krai. The lead ship should be put into operation by the beginning of 2027. Its cost may be approximately 100 billion rubles. Given the current financial and economic situation in Russia, it makes sense to consider 
the organization of competitive co-financing of the project by interested states, including South Korea, China and Japan. The formation of sustainable freight flows coming from these countries would be facilitated by an international icebreaking company, in which operational management would be these icebreakers and from the profits of their use this company would repay loans for construction of icebreakers.

At the same time, it should be kept in mind that if at the beginning of the XXI century the rate was placed on transit as the main factor in increasing freight traffic on the NSR, then after 2014 the situation has changed. Nowadays, the main cargo flow is formed by Russian projects in the Arctic, they provide the main share of traffic, although foreign transit is still important as a strategic prospect. At present, Russia in economic terms can no longer give it a priority and not overestimate its importance to maintain the profitability of the NSR. Last years have been characterized by the return of economic and scientific activity to the Russian Arctic, which is reflected in the need to supply fuel and lubricants to the region in volumes that cover both current operating costs and expenses caused by extraordinary circumstances, including the deterioration of the ice situation, natural disasters, a sharp increase in the necessary forces and means. Currently, these resources are manufactured in the central part of the country and are imported to the Arctic most often from the ports of Murmansk or Arkhangelsk.

To solve the above problems, an annual supply application is drawn up, the necessary tonnage of ships is allocated or chartered for it, a promising schedule for the delivery of resources is drawn up, based on the ice and weather conditions projected for the year ahead, and according to it, the so-called "Northern delivery" is carried out. Taking into account the low reliability of accurate forecasts in places of consumption of resources, as a rule, an additional annual reserve of current needs is formed, for which appropriate storage facilities are built. As a result, such a supply system has a one-year time lag in response to changes in the situation, it requires additional storage at the points of consumption for at least one year.

Deviations in the nomenclature and the volume of resources consumed are eliminated by air supplies from central supply bases, which is a very expensive process and not which is not always possible to perform. But over the past 20 years, the situation in the Russian Arctic has changed significantly. Large oil fields began to be developed there.

The current scheme for the delivery of crude oil from the Arctic fields of Russia includes shuttle tankers (ST) with a deadweight of up to 70 thousand tons for transportation, storage tanker of an enhanced ice class with a deadweight of up to 360 thousand tons for its reception, storage and transshipment to tankers-carriers (TC) with a deadweight of up to 200 thousand tons

A large TC deployed in the ice-free Kola Bay allows, in comparison with direct delivery of crude oil to the consumer, a significant increase in the efficiency of export deliveries, since the scheme based on this reduces the duration of roundtrip flights of specialized ST that transport oil from Arctic fields and makes it possible to use direct delivery to consumers of crude oil standard heavy duty TC.

Arctic STs, for example, "Kirill Lavrov", "Mikhail
Ulyanov" with a deadweight of 70 thousand tons each, unlike linear TCs, belong to the reinforced ice class as noted above, therefore they have icebreaking bow and stern forms, which allows them to work without icebreaker support in ice up to $1.2 \mathrm{~m}$ thick. They are capable of independently mooring without a tug to sea platforms in ice conditions and, as a consequence, dynamically keep their place near the platform under the influence of ice and wind when crude oil is pumped from it (they have special nasal system for receiving cargo in Arctic weather conditions). For transport and rescue operations, a helipad is provided.

The mentioned above additional equipment is not installed on a standard TC, therefore the cost of its construction and operation is significantly lower than that of the Arctic ST, therefore it is economically inexpedient to use them where conventional TCs can carry out the tasks of transporting crude oil. A logistic analysis of the existing crude oil delivery scheme shows that it is economically feasible to move the storage tanker as close to the ice edge as possible.

According to the authors, the Belushya Guba Bay on the Novaya Zemlya archipelago may be a convenient place to place storage tankers in their proposed crude oil delivery scheme. The area of Belushya Guba Bay is located in the zone of influence of the warm Gulf Stream, where the width of the ice fast ice does not exceed $1 \mathrm{~km}$ with an ice thickness of not more than $1 \mathrm{~m}$ even in the most severe winters. The depth at the entrance to the bay is $29-51 \mathrm{~m}$, in the places of possible mooring of storage tankers $-20-30 \mathrm{~m}$. The water area of Belushi Guba itself is sheltered from the wind and drifting ice. These circumstances will enable TCs to walk in the area yearround with minimal icebreaking support. It is important to note that Belushya Guba is located $140 \mathrm{~km}$ from the world's largest yet undeveloped deposit of metals such as manganese, lead, silver, zinc. Thus, the placement of storage tankers there can give an impetus to the beginning of the economic development of the entire promising region.

By assessing the possible costs for the relocation of storage tankers in Belushya Bay we should take into account the fact that the lease of the water area there is significantly lower than in the Kola Bay. It is also important to take into account the fact that storage tanker today meets all the requirements of the register and therefore can change its location if necessary. In case of an unfavorable ice forecast, it can be transferred to the Kola Bay in order not to expose the TC to the risk of swimming in ice conditions. Experience shows that such a state of ice on the Eastern side of the Novaya Zemlya archipelago is observed every 4-5 years and lasts no more than 1, 5-2 months. Hence, it can be concluded that the unfavorable ice conditions will not have a significant impact on the economic efficiency of the proposed scheme of transportation of crude oil from the Arctic fields.

Assessing the advantages of the proposed scheme, the fact should be taken into account that crude oil is currently supplied from the polar regions of Russia to the countries of Western Europe, since the delivery shoulder there is minimal, and the demand is quite sufficient. However, the growth of shale oil production in the US makes the market of these countries very competitive for our oil. Economic sanctions worsen the conditions of oil exports. The lack of effective 
alternatives for its sale in Western Europe can significantly reduce the price of crude oil from Russia's polar fields, so it is important to have a proven scheme for delivery to the AsiaPacific region (APR) through the Arctic. The trade war between the US and China creates certain prospects for this.

The innovative scheme for the delivery of Arctic crude oil to the Asia-Pacific region (APR) through the Arctic implies the placement of a second storage tanker in the East of Russia, for example, in the Bay of Providence. As a result, it will include a storage tanker to the West in Belushya Bay, and a storage tanker to the East in Providence Bay. Oil delivery to them from the Arctic will be carried out by tankers -shuttles.

\section{DETAILS OF LOGISTICS SCHEMES IMPLEMENTATION}

The mentioned above logistics scheme is quite feasible. Its broad consideration in the scientific press by itself can make a favorable impression on interested persons abroad for the Russian Federation and indirectly contribute to an increase in the quotation of domestic crude oil from the Arctic fields.

The economic efficiency of the proposed logistics scheme can be increased by refining crude oil directly on a board of the tanker-shuttle. By making this, two following objectives can be achieved: the delivery of finished petroleum products to the final destination, as well as the supply of facilities along the ST route with the necessary fuel and lubricants.

The possibility of such processing relies on the experience of the Moscow LLC "Energoprominzhiniring" which has created the relevant installation that operates even with a strong roll of the vessel. This unit can process about 3.9 thousand tons of crude oil per day and it has a modular design that allows flexible response to the demand for finished oil products both on the ST route and on the APR markets.

ST, like the tanker "Mikhail Ulyanov", should have a platform for basing / landing a helicopter that could transfer small quantities of fuel and lubricants and cargo to points located along the route of the Northern sea. The modified ST could accept applications for fuel from points along its route in 5-7 days. When ST reaches the traverse of the point, it will be able to transfer by helicopter ordered and manufactured batches of fuel and lubricants or directly to the customer, or unload them on the ice, in a place where it is possible to land the helicopter and store the cargo for a short time.

Temporarily stored fuels and lubricants are picked up by the supply vessels following in the ordered point, or are taken out by the helicopters based in it. The latter scheme is particularly interesting if the distance from ST at the time of shipment to the ordered fuel point exceeds the range of the helicopter from the ST board, or the weather in the ordered fuel point does not allow landing/taking off there.

Tracking the movement of the ice floe, where fuel and lubricants are temporarily stored, and their safety can be organized both with the help of traditional means built on the use of satellite radio navigation systems and satellite communication systems, and with the help of advanced tools presented in the work.

The relatively long presence of a number of STs, which move on a schedule, have a helipad and virtually unlimited reserves of aviation kerosene, allows them to be used as jump airfields and refueling points in the organization of helicopter flights over long and ultra-long distances, for example, when distilling helicopters, organizing scientific research, tourist events.

As a result of the implementation of the proposed measures in the Russian sector of the Arctic, a flexible commercially viable system of transportation and partial processing of hydrocarbon raw materials can be implemented, capable of ensuring national security, both in this area, and the country's economic interests in the energy markets in Western Europe and the APR countries.

In the event of an emergency in the Russian sector of the Arctic, a stable self-sufficient fuel and fuel supply system for key facilities in this situation will function.

The practical implementation of the above logistic schemes of transportation of liquid hydrocarbons is being designed to promote creation of cargo hubs in the Bay Belushya Lip and the Providence Bay between which will be running specialized ice-class vessels with or without the support of icebreakers (depending on ice conditions).

The use of such vessels in conditions adequate to their capabilities will significantly reduce the cost of cargo delivery. The costs of creating such cargo hubs, including capacities for partial processing of raw materials in sparsely populated areas, are relatively large, but the implementation of the "Porto-Franco" scheme, exemption from taxes for a long period, the provision of land for a long free lease can attract investors, especially from the PRC, which, due to already incurred costs in the North Atlantic, is forced to develop the Arctic region, relying today on remote national bases.

However, bilateral cooperation with China may be extremely burdensome for Russia in the foreseeable future, since the imbalance of economic power of the two states will continue in the near future. Therefore, it is advisable to build an Arctic logistics alliance at least by including Russia, China, South Korea and Japan, without being embarrassed by the fact that different states and specific investors can enter the Alliance at different times. The only restriction should be the rule that later joining must partially repay the full members of the Alliance already incurred costs and members of the Alliance should have the right to veto the entry of new members into the Alliance. This order activates those who want to not miss their chance to work effectively in the Arctic. One of them may even be so distant from the Arctic countries like India, which implements the using of storage tanks in the Providence Bay within achieving the task of creating strategic oil reserves [7], or Iran, which is currently engaged in terms of sanctions in the replacement scheme of delivery of oil to international markets.

It should be noted that China's economic activity in the Arctic region resonates among the Nordic countries. They are putting forward the plan named "Arctic corridor" which is being coordinated within the initiative "Ice Silk Road", and are going to invest at least 3 billion euros in the construction of the railway, which will stretch from the depths of Western Europe through the Finnish capital Helsinki to the Norwegian port of Kirkenes on the Barents sea.

The complication of relations between China and the United States, as well as the desire of the Chinese leadership to accelerate the development of the North-East of the country 
generated interest in the development of the Harbin Yakutsk - Tiksi - Europe route. To a large extent, this project is based on the Amur-Yakutsk railway — partially operating (on the Skovorodino-Tommot section), partially under construction (on the Tommot-Yakutsk section) railway in Eastern Russia, linking the TRANS-Siberian railway (Transsib) and the Baikal-Amur mainline (BAM) with Yakutia. According to the initiative of China, further construction of transport infrastructure to the seaport of Tiksi is planned. The development of this project will contribute to the development of the transport system in the Eastern part of Russia. So the construction of a bridge across the Lena river near Yakutsk will allow you to combine Federal highway "Lena", "Kolyma" to the road "Viluy", which will create considerable part of the Northern latitudinal belt of Russia, connecting by the shortest route through the territory of Yakutia in Eastern Siberia with the ports of the Okhotsk sea, this will include the transportation and logistics spatial coherence $18 \%$ of territories of the Russian Federation.

Multimodal transport logistics hub near the village of Nizhny Bestyah near Yakutsk will provide interaction of all modes of transport, terminal and warehouse facilities, information systems, financial and insurance support of goods. It will change the logistics of transportation, reduce the volume of river traffic in the upper reaches of the Lena river, where recently was detected a risk of navigation disruption associated with shallow water, will provide year-round communication with the all-Russian network of roads, Railways, which will provide transmodal mobility of the population.

Russian-Chinese activity in the creation of the Harbin Yakutsk - Tiksi - Europe route is likely to lead Japan to analyze the potential benefits of this undertaking for the national economy. Here, the attention of the Japanese side should be drawn to the project of construction of a road-rail crossing through the Tatar Strait, from the mainland to Sakhalin, which can begin in 2021 and will last five years. An obvious extension could be the long tunnel $42 \mathrm{~km}$ under the Strait of La Perouse on the Japanese island of Hokkaido, which will provide an outlet for Japanese goods in the port of Tiksi and further to Europe via the NSR. The construction of the tunnel is a long process, changing the direction of transportation of goods will also take more than one year, so at the first stage Japanese cargo to Sakhalin can be transported by ferries.

In total, the above transport and logistics schemes implemented in the Arctic zone of Russia with the involvement of foreign partners can bring real economic benefits to both its participants and the entire world economy, since their implementation will require the development of high-tech industries on the one hand, and on the other hand will reduce the cost of consumer goods in the markets of the countries involved in the new movement of goods by reducing transport costs.

\section{REFERENCES}

[1] A. Ferris-Rothman, "Russia's Suez Canal? Ships start plying a less-icy Arctic, thanks to climate change", The Washington Post.
[2] Zhuravel V.P. China, Republic of Korea, Japan in the Arctic: politics, economy, security // The Arctic and The North. 2016. № 24. P. 77-83.

[3] Qin Dong, Lukin A.L. Prospects for cooperation between Russian and Chine and the Russian Far East // Oykumena. 2018. №4. P. 158-167.

[4] Danilov A.P. China and the Arctic // Problems of the Far East. 2014. № 3. P. 67-73

[5] Grigoriev M.N., Uvarov S.A. Logistics. Basic course. Textbook. $4^{\text {th }}$ edition, M., Yurayt, 2017. - 836 p. Series: Bachelor. Academic Course.

[6] Dybskaya V.V., Zaitsev E.I., Sergeev V.I., Sterligova A.N. Logistics: Textbook. - M.: Eskmo, 2008. 944 p. - (Full MBA course).

[7] Grigoriev M.N., Kefeli I.F., Petrov A.N., Uvarov S.A. Logistic analysis of foreign experience in creating strategic oil reserves in order to strengthen the national security of the country // In the collection: Innovation technologies and technical means of special purpose Proceeding of the VIII All-Russian Scientific and Practical Conferense. Ser. "Library of the magazine "Voenmeh. Bulletin of BSTU' 2016. P. 287-299.

[8] Grigoriev M.N., Koroleva E.A., Uvarov S.A. The Northern Sea Route and the concept of chain management in the system of ensuring national security of Russia// In coll. Innovative technologies and technical means for special purposes: Proceedings of the tenth All-Russian Scientific and Practical Conference. In 2 volumes Vol. 2 BSTU "VOENMEH". SPb., 2018, p.. 81-87. 